\title{
SINGAPORE IN MALAYSIA: AN EXAMINATION OF ARGUMENT STRUCTURES IN A MALAYSIAN HISTORY TEXTBOOK
}

\author{
David Yoong $^{1}$, Kumaran Rajandran $^{2 *}$ and Rubini Devi Suppiramaniam ${ }^{1}$ \\ ${ }^{1}$ Faculty of Languages and Linguistics, University of Malaya, MALAYSIA \\ ${ }^{2}$ School of Humanities, Universiti Sains Malaysia, MALAYSIA \\ *Corresponding author: kumaranr57@gmail.com
}

Published online: 25 September 2017

To cite this article: Yoong, D., K. Rajandran and R. D. Suppiramaniam. 2017. Singapore in Malaysia: An examination of argument structures in a Malaysian history textbook. Kajian Malaysia 35(2): 67-85. https://doi.org/10.21315/km2017.35.2.4

To link to this article: $\mathrm{https} / / /$ doi.org $/ 10.21315 / \mathrm{km} 2017.35 .2 .4$

\begin{abstract}
The article explores how the Malaysian Form 3 history textbook portrays Singapore's merger and separation. The portrayal can influence the perception of Singapore among Malaysians. Singapore was part of Malaysia for about two years (1963-1965) and its brief union represents a crucial historical episode. The episode is analysed using Toulmin's argument structures. The analysis identifies the claims, grounds and warrants for the arguments, and it also examines the use of lexicogrammatical and intertextual features. Certain arguments articulate the benefits of the merger and it is endorsed by foreign and local leaders, and the general population. Subsequently, other arguments articulate the threats which Singapore posed and its separation is made to seem inevitable. The textbook portrays Singapore as an enthusiastic partner and later a distrusted partner of the Malaysian Federal Government. Its arguments validate the state-sanctioned version of history. The article also provides four proposals to improve history textbooks.
\end{abstract}

Keywords: Toulmin model, arguments, history, textbook

\section{INTRODUCTION}

Malaysians who sit for the national Penilaian Menengah Rendah (PMR), Form Three Assessment (Pentaksiran Tingkatan Tiga [PT3]) and Sijil Pelajaran Malaysia (SPM) examinations would have had some exposure to history textbooks. These obligatory readings, sanctioned by the Ministry of Education, relate official 
historical narratives. Narratives which are imbibed with little or no reflection are problematic because they influence the collective memory of citizens (Williams, 2014). Students may acquire an unrepresentative version of Malaysian history and be biased towards certain historical episodes (Rajandran, 2013). A narrative which promotes a particular argument often reflects the consensus of powerful groups, and it may reproduce an ethnocentric or nationalist portrayal of history (van Dijk, 2008). Conversely, an emphasis on selected episodes and the inclusion or exclusion of certain details can convey a more robust narrative.

Previous research on history textbooks considered how historical episodes and their participants are represented. Among these studies are: Barnard (2003) noting how Japan's Imperial Army, but not Japan (the country), is the agent for World War II atrocities; Moss (2010) explaining the use of non-human agents to imply inevitable progress in Colombian history; Oteíza and Pinto (2008) pointing out how the military's misdemeanors are vague and insignificant in Chilean and Spanish history; and Rajandran (2013) studying how the British and Malaysians are given diametric agencies (the British as agents of colonisation and the Malaysians as agents of independence). Scholars have also examined how historical episodes and their participants are evaluated. Some of their findings are: British colonisation is evaluated negatively but the Malayans' and Singaporeans' struggle for independence is evaluated positively (Rajandran, 2013, Tann, 2010); and the pre-military Chilean government is evaluated as incompetent (Oteíza, 2003).

The article analyses Singapore's period in Malaysia, which involves its merger and separation because it forms a significant episode in modern Malaysia and also marks the birth of a new country, Singapore. The analysis explores how the official narratives are portrayed through argument structures, which can shape the mental schemas of Malaysians about Singapore. These arguments can create unwanted antagonism, which may jeopardise Malaysia-Singapore relations. The arguments about why Singapore should join and later leave Malaysia are identified using the Toulmin model. The use of lexicogrammatical and intertextual features is also considered. These arguments merit examination since historical truth is rhetorical (Coffin, 1997), where language can influence the perception of historical episodes. The article also provides proposals on how history textbook authors may improve their narratives.

\section{MALAYSIA-SINGAPORE RELATIONS}

The narrow Tebrau Strait separates Malaysia's southern Johor state and Singapore but Malaysia and Singapore share a close political and social relationship. Singapore was part of the Johor Sultanate for three centuries before the British colonised Singapore in 1819. The British expanded their dominion in South East 
Asia during the 19th century and administered Singapore with Penang and Melaka through the Straits Settlements from 1826-1946. Penang and Melaka joined the Federation of Malaya in 1946 but Singapore remained a separate colony until it formed the Federation of Malaysia on 16 September 1963 with Malaya, Sabah and Sarawak.

The nascent federation faced external problems (opposition from Indonesia and the Philippines) and internal problems (ethnic unrest, leftist insurgency) (Sopiee, 2005). These problems were compounded by conflicts between the Federal and Singapore Governments. The Federal Government was led by Tunku Abdul Rahman of the Alliance Party, a coalition of ethnic-oriented parties which the United Malays National Organization (UMNO) dominated and the Singapore Government was led by Lee Kuan Yew of the People's Action Party (PAP), a multiethnic party. PAP and UMNO contested the 1964 general elections in Malaya and Singapore respectively, which breached a consensus to avoid contests in one another's sphere of influence. PAP campaigned for a Malaysian Malaysia and considered the special privileges for the majority Malay and bumiputera population discriminative. The Federal Government imposed constraints for Singapore's economy despite establishing a common market. These conflicts arose because PAP and UMNO had a distinct vision for Malaysia. Ultimately, the Federal Government separated Singapore from Malaysia on 9th August 1965.

After the separation, several bilateral disputes emerged, mostly regarding land and water (Nathan, 2002). Malaysia and Singapore had claims on islets in the Tebrau Strait and sought the International Court of Justice to settle the claims. Singapore's land reclamation has irked Malaysia because it damages the marine ecosystem in the Tebrau Strait. Malaysia claimed sovereignty on land adjoining the railway tracks and the land of the railway station in Singapore. Malaysia provides half of Singapore's freshwater and has tried to increase its price because the price set before the separation was extremely low. Malaysia and Singapore have signed several agreements to resolve these disputes and the latest MalaysiaSingapore Points of Agreement in 2010 resolved most land and water disputes. These disputes were said to have tensed bilateral relations (Nathan, 2002). Former Malaysian Prime Minister, Mahathir Mohamad was a vociferous critic of Singapore and blamed the country for being unfriendly to Malaysia, juxtaposing Malaysia's friendly posture (Nathan, 2002). The subsequent Prime Minister, Abdullah Badawi improved bilateral relations, which the present Prime Minister, Najib Razak continues. He says that Malaysia-Singapore relations have "never been better" (Channel News Asia, 2015).

Malaysia and Singapore share several transportation links, and new links are being developed, notably the Malaysia-Singapore high speed rail. These links can strengthen economic links. Singapore is Malaysia's second largest trading partner (Ministry of International Trade and Industry [MITI], 2015) and 
the stronger Singaporean economy has enticed more than 400,000 Malaysians to work in Singapore (Malaysian Insider, 2015). Malaysia launched Iskandar in 2006, a development region in southern Johor opposite Singapore. It hopes to stimulate mutually beneficial growth in Johor and Singapore (Iskandar Regional Development Authority, 2014). Hence, Malaysia-Singapore relations experienced periods of tension and cooperation (Nathan, 2002) and the earliest exposure to these relations is probably provided in the history textbook.

\section{DATAAND METHODS}

The Form 3 history textbook is endorsed by the Malaysian Ministry of Education. The Ministry's Chief Director hopes that the textbook can "produce a dynamic, skilled and productive young generation, who is responsible to their religion and nation". His statement is expanded by the authors, who envision the textbook to impart "historical knowledge...prosocial values, examples and patriotism...to realise the service of leaders, to inculcate love of the nation and to build students' identity". Critical thinking is not mentioned although the Malaysian Education Blueprint emphasises it as one the skills that students should master (Ministry of Education Malaysia, 2013).

The textbook is utilised by Form 3 students, who are often 15 year olds. History is a compulsory subject for the PT3, which students have to take at the end of Form 3. Their national history syllabus explains the chronology of key episodes until the independence of Malaysia. It teaches about the country's triumph against colonialism, and aims to motivate students to "honor and preserve the country's independence and sovereignty" (Abdul Razaq et al., 2013: 229). The textbook's narrative of Singapore's merger and separation is provided in the final chapter (Chapter 7). The chapter involves the formation of the Federation of Malaysia, the opinions of various governments, the Indonesian confrontation and the reasons for separation.

The article adopts the Toulmin model of argumentation to identify the argument structures, which disclose topoi about Singapore's merger and separation. In critiquing Wodak's (2006) approach to topoi, Žagar (2010) argues for the Toulmin model because it is a structured and systematic way of reconstructing arguments, which helps to understand how arguments can create persuasive rhetoric. Topoi are "content-related warrants or conclusion rules which connect the argument or arguments with the conclusion, the claim. As such, topoi justify the transition from argument(s) to conclusion" (Žagar, 2010: 5).

Toulmin (2003) proposes three basic components in arguments: claim, grounds and warrants. Claim means the position argued for or against, and it can be regarded as the conclusion of the argument. Grounds are data, evidence or 
reasons to reinforce the claim. Warrants are the principal or chain of reasoning to justify the connection between the grounds and the claim. They "register explicitly the legitimacy of the step involved and refer it back to the larger class of steps whose legitimacy is being presupposed" (Toulmin, 2003: 92). The degree of persuasiveness in arguments increases if additional components are included, and these are backings, qualifiers and rebuttals. Backings provide the authority to strengthen the grounds. Qualifiers modify the certainty of the claim, warrant and backing. Rebuttals are reservations to the claim and are instances where the claim might not be true. Figure 1 demonstrates how these components are linked.

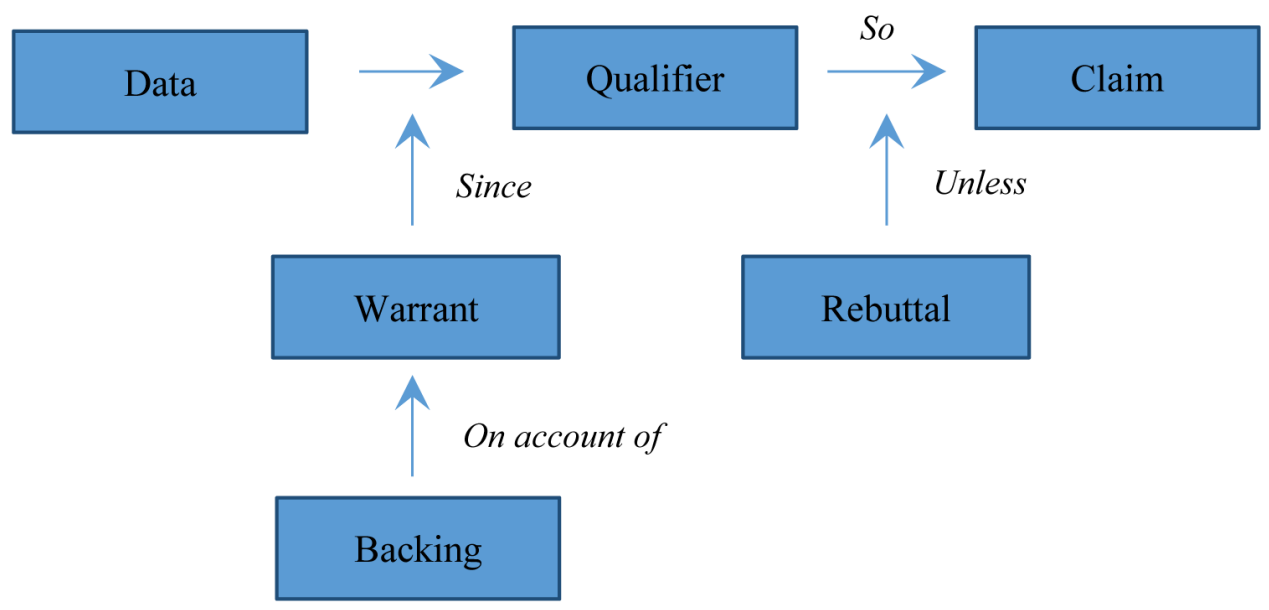

Figure 1: Toulmin's model of argumentation.

The analysis also examines lexicogrammatical features in the arguments, primarily the use of adjectives, nouns and verbs. Their paradigmatic choice presumes alternatives, which leave ideological traces. Historical episodes may be "reworded" as part of political and social struggles (Yoong, Tan and Ng, 2013: 235) and the choice of lexicogrammatical features can influence how historical episodes are portrayed. For instance, the clause The Federal Government separated Singapore from Malaysia identifies the Federal Government as the agent who has power or blame while the clause Singapore was separated from Malaysia absolves the agent. Other nouns can reword the agent, such as "Government" or "Alliance Party" and other verbs, such as "expel" or "remove" can reword "separated". The analysis also examines intertextual features, the implicit or explicit references to other texts (Fairclough, 1992). How these lexicogrammatical and intertextual features are deployed can indicate which perspective permeates in the textbook. Since the textbook is in Malay, the researchers translated the excerpts from Malay into English and a native user verified the translations. 


\section{Formation of Malaysia}

The examination of the arguments before Singapore's separation helps to understand why Singapore had to leave Malaysia. Although not stated, the general motif in the section about the formation of Malaysia is "hope". The previous chapters describe how the leaders and residents of Malaya, Sabah, Sarawak and Singapore experienced hardship under various colonial powers, World War II and leftist insurgency. The formation of Malaysia meant autonomy, power and unity for its people. The textbook presents two claims to describe the formation of Malaysia, which emphasise its advantages (Claim 1) and the response that it provoked (Claim 2).

\section{Claim 1: A federated Malaysia will create political stability, economic prosperity and social cohesion}

The textbook presents Claim 1 using a temporal shift, as if students are in the past and do not know the future. The claim predicts a number of consequences, which realise the grounds of the federation: (i) to hasten independence, (ii) to create ethnic balance, (iii) to advance development, and (iv) to create safety and stability. These objectives are presented in Excerpt 1.

\section{Excerpt 1: Objectives of the federation ${ }^{1}$}

\section{Hasten independence}

- The small size of Singapore and the extremely low population of Sarawak, Sabah and Brunei make it difficult to attain independence by themselves from the British

- To hasten the independence of Singapore, Sarawak, Sabah and Brunei

Ethnic balance

- To balance the Malay and bumiputera population with the non-bumiputera population in the Federation of Malaysia

Socio-economic development

- To create a wider market economy

- To consolidate human and natural resources among the states of the federation

- To abolish tax barriers among the federated states

- To ease efforts to attract foreign investors

- To improve the quality of life of citizens in Sarawak, Sabah and Brunei

National safety and stability

- To save Singapore and Sarawak from the communists

(p. 205) 
The lexicogrammatical features depict that only benefits can arise from the federation. The verbs are mostly action-oriented and create improvements: to hasten (independence) (Mempercepat kemerdekaan), to create (a wider common market) (Mewujudkan satu kawasan pasaran ekonomi...), to consolidate (human and natural resources...) (Menyatukan sumber tenaga manusia dan sumber asli), to abolish (tax barriers) (Menghapuskan sekatan cukai), to ease (efforts to attract foreign investments) (Memudahkan usaha untuk menarik pemodal luar), and to improve (lives) (Memajukan taraf hidup rakyat). These verbs eliminate the agent and the temporal frame, which introduce a sense of inevitability for the federation and its purported improvements.

Quantifiers are also noted, where "small size" and "extremely low population" (Saiz... yang terlalu kecil) imply a relative lack of authority and power, but these can increase when consolidated as a part of a greater country. The phrase "to balance ethnic groups" (Mengimbangi penduduk) shows a desire to equalise small and large groups. Other phrases, such as "to create a wider common market" (Mewujudkan satu kawasan pasaran ekonomi yang lebih luas) and "to consolidate human and natural resources" (Menyatukan sumber tenaga manusia dan sumber as $i$ ) introduce security in large numbers and expands wealth. The textbook lacks intertextual references for some of the consequences perhaps because they were conjectural.

Some background is required to understand Claim 1. Through various media, Malaysians have been informed that colonial powers transformed the political and social environment for the worse (Rajandran, 2013). Communism is also a vilified ideology in Malaysia. It is linked to instability and militancy, and considered a national threat, although the communists also helped the struggle for independence (Kua, 2011). From Excerpt 1, the warrant or topoi can be formed: Beneficial objectives in the creation of the federation will lead to political stability, economic prosperity and social cohesion. The textbook provides no rebuttal for the claim.

\section{Claim 2: The formation of Malaysia had overwhelming support}

Claim 2 employs three grounds: (i) The residents and leaders of the four territories (Malaya, Sabah, Sarawak, Singapore) welcomed the federation and endorsed it because they would enjoy political stability, (ii) the merger enables economic prosperity and social cohesion, and (iii) the British and American governments supported the federation as it would curtail communism (Excerpt 2). The textbook also features explicit intertextual references through newspaper excerpts, as in Excerpt 3. 
Excerpt 2: Support for the federation ${ }^{2}$

a. Tunku Abdul Rahman's speech is regarded as the idea about the formation of the Federation of Malaysia. This idea was received positively by the leaders of the involved states.

b. The Federation of Malaysia also received reactions from political parties in Singapore. The People's Action Party (PAP) under Lee Kuan Yew's leadership welcomed the formation of the Federation of Malaysia. This idea could save the party from being dominated by left-wing parties.

c. Generally, the residents of Malaya, Sabah, Sarawak and Singapore accepted the principles of the Federation of Malaysia.

d. The Federation of Malaysia received the support of the British and American governments. Both superpowers believed that the federation can hasten the independence of Singapore, Sarawak, Sabah and Brunei.

Excerpt 3: Intertextual references ${ }^{3}$

Berita Harian (newspaper) headline: Greater Malaysia: Tengku's proposal receives support

"That this House agreeing in principle with the concept of Malaysia comprising the eleven States of the federation, the States of Singapore and Brunei and the territories of North Borneo and Sarawak, endorses the Government's initiative in taking action for its realization, the progress of which will be reported to the House by the Honorable Prime Minister from time to time..." Parliamentary Debate, October 16, 1961, Vol. III(16)

(p. 203)

The textbook introduces another explicit intertextual reference through the Singapore referendum (Excerpt 4). It states that the Malaysian Department of Information reported that over $71 \%$ of Singaporeans voted for Alternative A. While $25.8 \%$ of votes were spoilt, the remaining votes were shared by Alternatives B and $\mathrm{C}$. The referendum did not provide a choice for voters to oppose the federation. 
It is a fait accompli but Singaporeans are projected as the decision-makers who favoured and therefore voted for merger.

Excerpt 4: Alternatives in Singapore referendum

\section{Alternative A}

I support merger giving Singapore autonomy in labor, education and other agreed matters as set out in Command Paper No. 33, 1961, with Singapore citizens automatically becoming citizens of Malaysia.

\section{Alternative B}

I support complete and unconditional merger for Singapore as a state on an equal basis with the other eleven states in accordance with the Constitutional documents of the Federation of Malaya.

\section{Alternative $C$}

I support Singapore entering Malaysia on terms no less favorable than those given to the Borneo territories.

(p. 207)

From Excerpts 2-4, the warrant can be formed: The strength of a movement is dependent on its number of supporters. The textbook has several instances of specific groups making the federation their objective. Yet, the textbook provides some rebuttals. Although most groups wanted the federation, some groups did not want it, notably conspiracy theorists, communists or Sulu Sultanate supporters, as seen in Excerpt 5.

\section{Excerpt 5: Rebuttal to Claim $2^{4}$}

However, the Socialist Front and the Singaporean People's Party considered the federation a British plan to maintain their influence.

Indonesia initially supported the Federation of Malaysia...Despite this, Indonesia changed its stance because it was influenced by the Communist Party of Indonesia (PKI) which accused the federation of neocolonialism. In truth, PKI felt threatened by the formation of the Federation of Malaysia, which would restrict its influence... The Philippines also opposed the federation because it claimed that Sabah was part of the Sulu Sultanate. However, the British did not entertain this claim because it had no basis. 
The phrase, "in truth", comes after explaining PKI's accusation. It implies that the prior statement is not the truth and the "truthful" alternative discloses PKI's insecurities. Excerpt 5 favours certain interpretations. Those who did not support Malaysia were suspicious (it is a British conspiracy), psychologically insecure (the Indonesians feel threatened) and greedy (the Philippines wants territory). These interpretations posit an ingroup-outgroup dichotomy, where the ingroup is "good" for wanting political, economic and social progress, but the outgroup is "bad" for obstructing it. The ingroup represents the future and its benefits while the outgroup represents the past and does not wish change to happen. Therefore, the formation of Malaysia is the future and most groups accept it, except some who remain in the past.

\section{SEPARATION OF SINGAPORE}

While the textbook's earlier section explains the formation of Malaysia positively, the separation of Singapore from Malaysia is marked negatively. Singapore and particularly Lee Kuan Yew are portrayed as antagonistic to the Federal Government. The textbook justifies Singapore's separation through a claim with four grounds: (i) Singapore created economic problems for Malaysia, (ii) Singapore wanted a Malaysian Malaysia, (iii) PAP's leadership created ethnic strife, and (iv) PAP had discords with the Alliance Party. These grounds are further elaborated, as shown in Excerpt 6.

Excerpt 6: Singapore exhibits antagonistic behaviours ${ }^{5}$

Economic problems

- Singapore demanded that its status as a center of industry, trade and free port not be contested by the federal government

- Singapore demanded tax privileges from the federal government

Malaysian Malaysia concept

- Singapore demanded equal rights for all people regardless of race

- Singapore denied the monarchy and opposed the special privileges of the Malays and bumiputeras

Ethnic riots

- Many statements issued by PAP leaders incited racial sentiments

- The racial riots in Singapore jeopardized national security 
Disagreements between the Alliance Party and PAP

- PAP accused the Malaysian Chinese Association (MCA) of not representing the interests of the Chinese

- PAP contested against the Alliance Party in the 1964 elections in Peninsula Malaysia

(p. 226)

Certain lexicogrammatical features indicate agency in the grounds. Singapore and PAP perform detrimental activities, as seen in the actionoriented verbs: demanded (tax privileges) (menuntut keistimewaan cukai), denied (the monarchy) (menafikan institusi raja), and incited (racial sentiments) (membangkitkan sentimen perkauman). Singapore troubled the Federal Government by acting subversively. Singapore and PAP also seemed to be antiMalay and therefore racists (made hurtful ethnic remarks that caused ethnic unrest, questioned the monarchy, special privileges and the MCA), greedy (demanded tax privileges) and self-centered (would not share wealth).

Singapore contested the Federal Government because the latter's political and social policies did not match the former's vision for Malaysia. Singapore overextended itself and wanted to determine how the country was administered. PAP, a multiethnic party, is seen as a Chinese party because it criticised MCA, a professed Chinese-based party. PAP is also made to be isomorphic with Singapore and the activities of the party become the activities of the territory. PAP is identified as representing a Chinese-dominated Singapore, which is antagonistic to a Malaydominated Malaysia. The textbook provokes an ethnic dimension to distinguish Malaysia and Singapore, and diverts the focus from political and social problems.

Some background is required to understand the grounds. The Malay monarchy symbolises Malay dignity, heritage and status. Special privileges were accorded to the Malays and bumiputeras in education and employment to improve their economic status. The monarchy and special privileges were enshrined in the Constitution of Malaysia (Articles 32, 153 and 181). Any question about their legitimacy, such as Singapore's Malaysian Malaysia, is equated to treason because it is believed to threaten the country's founding principles. Singapore was not in line with the other territories because it questioned the monarchy and special privileges. Singapore became a threat to the status quo, which justifies its separation. Opinions, which are explicit intertextual references, are introduced as backing, as in Excerpt 7. 
Excerpt 7: Intertextual references ${ }^{6}$

PAP and its leader, Lee Kuan Yew often disputed the provisions enshrined in the Constitution of Malaysia. Lee Kuan Yew also intended to take over the role of MCA which represents the Chinese. Upon these considerations, the Prime Minister of Malaysia, Tunku Abdul Rahman decided to expel Singapore from the Federation of Malaysia. The Declaration of the Separation of Singapore was made in parliament on 9th August, 1965.

In summarizing his actions, Tunku Abdul Rahman explains, "... if we did not split up, there will be horrendous murders...". Meanwhile, Tun Abdul Razak, commenting on the same issue, said that expelling Singapore is akin to removing a thorn from the flesh. Clearly, the separation of Singapore from Malaysia is to ensure harmony, safety and unity among Malaysians of various races.

(p. 228)

The opinions of PAP, Lee Kuan Yew, and other Malaysians and Singaporeans about the separation are excluded. The opinions of two prominent politicians, Prime Minister Tunku Abdul Rahman and future Prime Minister, Tun Abdul Razak are included, and their opinions render Singapore a problematic territory. The textbook cites the present and future Prime Minister to convey their agreement and the coherence of opinions to expel Singapore. The leaders unanimously believed that to retain Singapore meant more ethnic strife. The textbook displays a bias through the word "clearly", which designates the indisputability of the opinions.

The warrant of the argument can be reconstructed: Bad partners must be expelled from the group. Singapore became dangerous by exhibiting antagonistic behaviours towards the Federal Government, which justified its separation. Singapore was the cause of its separation from Malaysia and the Federal Government should not be blamed. Instead, it exercised caution by removing Singapore to save the rest of Malaysia.

\section{DISCUSSION AND CONCLUSION}

The article has identified three major warrants about Singapore's merger and separation in the Malaysian Form 3 history textbook. These are: (i) beneficial objectives in the creation of a federation will lead to political stability, economic prosperity and social cohesion, (ii) the strength of a movement is dependent on its number of supporters, and (iii) bad partners must be expelled from the group. 
These warrants contain implicit positive-negative binary consequences, where great objectives can only be met if partners work together in large numbers and partners who would not cooperate are removed. Singapore was an enthusiastic partner but became a distrusted partner of the Federal Government. Since Singapore became antagonistic, its separation was inevitable. The warrants present Singapore favourably to justify the formation of Malaysia but unfavourably to justify its separation. Singapore is valued as long as it and the Federal Government are aligned. Inadvertently, the textbook states that Malaysia is workable if its component territories are amenable to the Federal Government. Interestingly, Singaporean history textbooks and other historical sources (e.g. Stockwell, 2004) depict the merger and separation in another way. ${ }^{7}$

The textbook cumulatively presents more aggregated data, backed with selected granular data. It contains more one dimensional analysis (aggregated data) than artifacts about the merger and separation (granular data). Where available, the artifacts are selected opinions while other opinions are absent, and the source of opinions creates a one-sided portrayal of historical episodes and their participants. The textbook does not seem to encourage students to explore holistic data and to develop their personal interpretation of history. Even if they did, their interpretation should be in line with the official narratives. Hence, the realisation of alternative interpretations is discounted from the textbook and other perspectives are not considered.

This approach to history may stifle students' critical thinking abilities. As Hobsbawn (1997 in Haydn et al., 2015: 17) reflects, "why do all regimes make their young study some history in school? Not to understand society and how it changes, but to approve of it, to be proud of it, to be or become good citizens". The history textbook is recruited by the state to achieve the socialisation of students as responsible and compliant citizens who would be proud of their country and contribute to maintain its ideals.

Improvements to history textbooks are desirable although there may be obstacles because understandably, the state prefers to control the narratives to retain its influence on citizens. The article provides four proposals to improve history textbooks and to inculcate critical thinking. Firstly, the primary purpose of the textbook should be to enlighten students about various countries, their historical episodes and important participants but it should be moderated by informed and sensible skepticism. Students must have access to more granular data to form their own aggregated opinions of historical episodes. They should be taught about the complexity of history, which can be broached from multiple angles (Haydn et al., 2015).

Secondly, students must know that history is shaped by ideological forces, which are prone to bias. History scholars have a shared consensus about history as devoid of objectivity and neutrality (Carr, 1962). Therefore, what should 
history textbook authors do? One option is to equip students with theoretical and philosophical frames of reference. If history is seen as an investigative process, then students should be encouraged to acquire thinking skills to triangulate data (Carr, 1962) and to achieve more informed conclusions, as promoted in the Malaysian Education Blueprint (Ministry of Education Malaysia, 2013).

Thirdly, the authors should be wary of the types of topoi, data and claims because these can convey one-sided realities about historical episodes. They should try to be neutral and incorporate extra artifacts (e.g. printed documents, visual and audiovisual records), even if these artifacts harbour contrary opinions to those that the textbook espouses. The introduction of these artifacts helps to formulate neutral claims and warrants. Complex rebuttals should also be available to furnish extra details. Lastly, the authors should mitigate bias by being aware of their use of lexicogrammatical and intertextual features because their representation and evaluation can shape the mental schemas of students. By implementing these four proposals, the quality of history textbooks could improve.

\section{NOTES}

1. Excerpt 1: Objectives of the federation

Mempercepat kemerdekaan

- Saiz Singapura dan jumlah penduduk Sarawak, Sabah dan Brunei yang terlalu kecil menyukarkan usaha memperoleh kemerdekaan secara bersendirian daripada British

- Mempercepat kemerdekaan Singapura, Sarawak, Sabah dan Brunei

Keseimbangan kaum

- Mengimbangipenduduk Melayu dan bumiputera dengan bukan bumiputera dalam Persekutuan Malaysia

Memajukan sosioekonomi

- Mewujudkan satu kawasan pasaran ekonomi yang lebih luas

- Menyatukan sumber tenaga manusia dan sumber asli di kalangan negeri dalam persekutuan

- Menghapuskan sekatan cukai di kalangan negeri persekutuan

- Memudahkan usaha untuk menarik pemodal luar

- Memajukan taraf hidup rakyat Sarawak, Sabah dan Brunei

Keselamatan dan kestabilan negara

- Menyelamatkan Singapura dan Sarawak daripada jatuh ke tangan komunis

(p. 205) 
2. Excerpt 2: Support for the federation

a. Ucapan Tunku Abdul Rahman dianggap sebagai idea penubuhan Persekutuan Malaysia. Idea ini mendapat sambutan positif daripada pemimpin-pemimpin wilayah yang terbabit.

b. Gagasan Persekutuan Malaysia juga mendapat reaksi daripada parti-parti politik di Singapura. Parti Tindakan Rakyat (PETIR) pimpinan Lee Kuan Yew mengalu-alukan gagasan Persekutuan Malaysia. Gagasan ini dapat menyelamatkan parti tersebut daripada dikuasai oleh parti-parti berhaluan kiri.

c. Secara keseluruhannya, penduduk di Persekutuan Tanah Melayu, Sabah, Sarawak dan Singapura menerima prinsip gagasan Persekutuan Malaysia.

d. Gagasan Persekutuan Malaysia mendapat sokongan daripada kerajaan Britain dan Amerika Syarikat. Kedua-dua kuasa besar ini menganggap gagasan Persekutuan Malaysia dapat mempercepat proses kemerdekaan Singapura, Sarawak, Sabah dan Brunei.

3. Excerpt 3: Intertextual references

Melayu Raya: Chadangan Tengku dapat sambutan

4. Excerpt 5: Rebuttal to Claim 2

Walaupun begitu, Barisan Sosialis dan Parti Rakyat Singapura menganggap gagasan Persekutuan Malaysia sebagai satu rancangan pihak Britain untuk mengekalkan pengaruhnya.

(p. 206) 
Indonesia pada mulanya menyokong gagasan Persekutuan Malaysia... Walaupun begitu, pendirian Indonesia berubah kerana terpengaruh dengan dakyah oleh Parti Komunis Indonesia (PKI) yang menuduh gagasan tersebut sebagai neokolonialisme. Sebenarnya, PKI berasa tergugat dengan pembentukan gagasan Persekutuan Malaysia yang akan menyekat pengaruhnya... Filipina juga menentang gagasan Persekutuan Malaysia kerana mendakwa Sabah adalah sebahagian daripada wilayah Kesultanan Sulu. Namun, pihak British tidak melayan tuntutan tersebut kerana tidak berasas.

(p. 212)

5. Excerpt 6: Singapore exhibits antagonistic behaviours

Masalah ekonomi

- Singapura menuntut agar statusnya sebagai pusat perindustrian perdagangan dan pelabuhan bebas tidak disaingi oleh kerajaan pusat

- Singapura menuntut keistimewaan cukai daripada kerajaan pusat

Konsep Malaysian Malaysia

- Singapura menuntut hak sama rata untuk semua rakyat tanpa mengira kaum

- Singapura menafikan institusi raja dan menentang hak istimewa orang Melayu dan bumiputera

Rusuhan kaum

- Banyak kenyataan yang dikeluarkan oleh pemimpin PETIR membangkitkan sentimen perkauman

- Rusuhan kaum yang berlaku di Singapura menggugat keselamatan negara

Pertikaian Parti Perikatan - PETIR

- PETIR menuduh MCA tidak mewakili kepentingan kaum Cina

- PETIR bertanding menentang parti Perikatan dalam pilihan raya pada tahun 1964 di Semenanjung Malaysia

(p. 226) 
6. $\quad$ Excerpt 7: Intertextual references

PETIR dan pemimpinnya iaitu Lee Kuan Yew sering mempertikaikan peruntukan yang telah termaktub dalam Perlembagaan Malaysia. Lee Kuan Yew juga berhasrat mengambil alih peranan parti MCA yang mewakili kaum Cina. Atas pertimbangan inilah Perdana Menteri Malaysia, Tunku Abdul Rahman membuat keputusan untuk menyingkirkan Singapura daripada Persekutuan Malaysia. Pengisytiharan Pemisahan Singapura dari Malaysia dibuat di parlimen pada 9 Ogos 1965.

Dalam merumuskan tindakan beliau, Tunku Abdul Rahman menjelaskan, "... jika kita tidak berpisah, sudah pastilah akan berlaku pembunuhan yang menggerunkan...". Sementara itu, Tunku Abdul Razak dalam mengulas perkara yang sama, beliau menyatakan tindakan memisahkan Singapura sebagai menyingkirkan duri dalam daging. Jelasnya, pemisahan Singapura daripada Malaysia adalah untuk memastikan keharmonian, keselamatan dan perpaduan rakyat Malaysia yang terdiri daripada pelbagai kaum.

(p. 228)

7. While the textbook credits Tunku Abdul Rahman for conceiving the concept of the federation, and Lee Kuan Yew agreed to it, other sources indicate alternative and complex realities. Stockwell (2004) explains how Lee Kuan Yew sent Tunku Abdul Rahman a confidential paper to propose the merger on 9 May, 1961. Lee feared revolts from radicalised parties, which threatened national and regional security. Yet, Tan (2011) argues for the British policymakers, who wanted the merger to establish one independent country.

\section{REFERENCES}

Abdul Razaq Ahmad, Mohd Mahzan Awang, Ahmad Ali Seman and Ramle Abdullah. 2013. The skills of using history textbooks in secondary school. Asian Social Science 9(12): 229-236.

Barnard, C. 2003. Pearl Harbor in Japanese high school history textbooks. In Re/reading the past: Critical and functional perspectives on time and value, eds. J. Martin and R. Wodak, 247-271. Amsterdam: John Benjamins. https://doi.org/10.1075/ dapsac.8.14bar.

Carr, E. 1962. What is history? New York: Alfred Knopf.

Channel News Asia. 2015. Singapore-Malaysia relations never better: PM Najib Razak. http://www.channelnewsasia.com/news/singapore/singapore-malaysia/1827498. html (accessed 27 February 2017). 
Coffin, C. 1997. Construction and giving value to the past: An investigation into secondary school history. In Genre and institutions, eds. F. Christie and J. Martin, 196-230. London: Cassell.

Fairclough, N. 1992. Discourse and social change. Cambridge: Polity Press.

Haydn, T., A. Stephen, J. Arthur and M. Hunt. 2015. Learning to teach history in the secondary school: A companion to school experience. 4th ed. London: Routledge.

Iskandar Regional Development Authority. 2014. FAQ. http:/www.iskandarmalaysia. com.my/faq (accessed 27 February 2017).

Kua, K. S. 2011. Patriots and pretenders. Petaling Jaya: SUARAM.

Malaysian Insider. 2015. Rakyat Malaysia sanggup ambil risiko demi pendapatan lumayan di Singapura. http://www.themalaysianinsider.com/bahasa/article/ rakyat-malaysia-sanggup-ambil-risiko-demi-pendapatan-lumayan-di-singapura (18 February 2016).

Ministry of Education Malaysia. 2013. Malaysian Education Blueprint 2013-2025. Putrajaya: Kementerian Pendidikan Malaysia.

Ministry of International Trade and Industry (MITI). 2015. MITI report 2014. Petaling Jaya: Ministry of International Trade and Industry Malaysia.

Moss, G. 2010. Textbook language, ideology and citizenship. Functions of language 17(1): 71-93. https://doi.org/10.1075/fol.17.1.03mos.

Nathan, K. 2002. Malaysia-Singapore relations: Retrospect and prospect. Contemporary Southeast Asia 24(2): 385-410. https://doi.org/10.1355/CS24-2I.

Oteíza, T. 2003. How contemporary history is presented in Chilean middle school textbooks. Discourse \& Society 14(5):639-660.https://doi.org/10.1177/09579265030145005.

Oteíza, T. and T. Pinto. 2008. Agency, responsibility and silence in the construction of contemporary history in Chile and Spain. Discourse \& Society 19(3): 333-358. https://doi.org/10.1177/0957926508088964.

Rajandran, K. 2013. Us and them: The portrayal of Malaysians and British in Malaysian history textbooks. Journal of African and Asian Studies 48(3): 313-331. https:// doi.org/10.1177/0021909612455473.

Sopiee, M. 2005. From Malayan Union to Singapore Separation. Kuala Lumpur: University of Malaya Press.

Stockwell, A., ed. 2004. Malaysia: British documents on the end of Empire. https:// ia600505.us.archive.org/33/items/205722212TheMakingOfTheFederationOfMa laysia/205722212-The-Making-of-The-Federation-of-Malaysia.pdf (accessed 27 February 2017).

Tan, M. J. 2011. Singapore's role in Indonesia's confrontation of Malaysia and the impact of confrontation on Singapore-Indonesia relations. Singapore: National University of Singapore.

Tann, K. 2010. Imagining communities: A multifunctional approach to identity management in texts. In New discourse on language, eds. M. Bedranek and J. Martin, 164-194. London: Continuum.

Toulmin, S. 2003. The uses of argument (Updated ed.). Cambridge: Cambridge University Press.

van Dijk, T. 2008. Discourse and power. New York: Macmillan. 
Williams, J. 2014. Foreword to the series. In (Re)Constructing memory: School textbooks and the imagination of the nation, ed. J. Williams, vii-x. Rotterdam: Sense Publishers.

Wodak, R. 2006. The discourse-historical approach. In Methods of critical discourse analysis, eds. R. Wodak and M. Meyer, 63-94. London: Sage.

Yoong, D., H. K. Tan and C. M. Ng. 2013. 'This is not gambling but gaming': Methods of promoting a lottery gaming company in a Malaysian daily. Discourse \& Society 24(2): 229-247. https://doi.org/10.1177/0957926512469433.

Žagar, I. 2010. Topoi in critical discourse analysis. Lodz Papers in Pragmatics 6(1): 3-27. https://doi.org/10.2478/v10016-010-0002-1. 
